\title{
SYSTEMATIZATION OF COMPONENTS OF COMPETENCE OF SUBJECTS OF FREE LEGAL AID PROVISION IN UKRAINE: ADMINISTRATIVE AND LEGAL ASPECT
}

\author{
Volodymyr Marchenko ${ }^{1}$ \\ ${ }^{I}$ Doctor of Law, Professor, Professor of the Department of State-Legal Disciplines, Criminal Law and Process, G. S. \\ Skovoroda Kharkiv National Pedagogical University, e-mail: marchenko2210@gmail.com, ORCID: \\ https://orcid.org/0000-0003-1921-3041
}

Abstract. In the article, the author defines the general subject of conducting subjects for the provision of free legal assistance, systematizes their rights and obligations (powers), as well as conducts a generalized analysis and identifies common competency blocks for entities providing free legal assistance. So, the subject of reference in this case determines the scope of the provision of free legal assistance. The competence of local governments that provide free primary legal assistance (executive bodies of rural, village, city councils), which consists of the following blocks: is determined: professional; organizational and managerial; control; informational; associative; scientific and methodological and logistics unit. Specialized institutions that provide free primary legal assistance implement the following competency blocks: professional; organizational and managerial; informational and analytical and normative. The competence of regional centers for the provision of free secondary legal assistance consists of: a professional unit; analytical unit; monitoring unit; methodological and educational unit; strategic block; personnel block; associative block; regulatory unit. The structural blocks of competence of local centers for the provision of free legal assistance in their content are similar to the competence of regional centers with minor differences: professional block; analytical unit; organizational unit; methodological and educational unit; strategic block; personnel block; associative block; regulatory unit. The competency blocks of the subjects of the provision of free legal assistance make it possible to form an objective idea of their general competence, to establish the similarity of its individual elements with each other. It is noted that the difference between the individual blocks of competence mainly depends on the level and volume of implementation of such competence by the subjects of the provision of free legal assistance and the types of the latter - primary or secondary. It is concluded that the general competence of the subjects for the provision of free legal aid consists of a set of rights and responsibilities, which are proposed to be combined into such blocks as: professional, regulatory, organizational and managerial, control, monitoring, personnel, strategic, analytical, informational, logistical, methodological and educational, scientific, associative.

Keywords: powers, rights and obligations, subject matter, public receptions, local authorities, specialized agencies for the provision of free primary legal assistance, centers for the provision of free legal assistance.

JEL Classification: K19, K30

Formulas: 0; fig.: 0; tabl.: 0; bibl.: 13

Introduction. By studying the institutional component of the administrativelegal mechanism of free legal aid, it is impossible to reveal the essence of such a mechanism, because the subjects are only one of its components, including: principles, forms and methods of specific activities, administrative law, legal relations, etc. . In general, the mechanism of administrative and legal regulation can be defined as a set of legal means used for the purpose of legal regulation of administrative legal relations. Without delving into the essence of the concept of "legal remedy", we emphasize the importance of clarifying the clear scope of competence of the subjects, in particular those who provide free legal aid. Because 
the subjects of free legal aid in case of deprivation of their competence are not able to perform any task set before him, including strategically important - the protection of human rights, freedoms and interests.

Without a clear legally defined competence of the subjects of free legal aid, they will not be able to "activate" other elements of the administrative-legal mechanism, such as using certain means or implementing the relevant principles, and will not be able to become a party to legal relations. Thus, the competence of the subjects of free legal aid is a "link" of the elements of the administrative-legal mechanism, as well as an element of the administrative-legal status of the vast majority of subjects of free legal aid.

Literature Review. Issues related to the definition of the limits of competence of the subjects of free legal aid have remained out of the attention of modern jurisprudence. In turn, to eliminate the relevant theoretical gap, which is also of practical importance, a number of legal acts regulating the activities of these entities were analyzed. At the same time, the study used the provisions and conclusions on the content of the concept of "competence" of such scientists as: VB Averyanov, DM Bakhrakh, Yu. P. Bytyak, II Dakhova, BV Rossinsky, OF Skakun, Yu. N. Starilov, Yu. A. Tikhomirov.

Aim. The purpose of the article is to determine the specific components of the competence of the subjects of free legal aid and as a result of their assessment of the classification of the first.

Methods. The comparative method, methods of analysis and synthesis are the basis of the research methodology presented in the article.

Results.. Given the importance of the competence of the subjects of free legal aid, on which depends the procedure and quality of legal services, we consider it necessary to dwell in more detail on the concept of "competence".

In a general sense, competence is: "the right granted to someone to do something; in the plural - the rights granted to a person or enterprise by the authorities "[1, p. 1000]; "Awareness, experience in a particular field, a question; availability of powers, sovereignty "[2, p. 460]. In the legal plane, the understanding of competence tends to the legal rather than the professional aspect, and is defined as "a set of subjects of competence, functions, powers, rights and responsibilities of the executive body, official" [3, p. 210]. Some scholars, such as OF Skakun, identify competence with areas of activity that follow from the functional purpose of the subject [4, p. 394]. We consider this approach to be biased, as it is impractical to replace the category of competence with another category - areas of activity, because they are different in nature, because competence determines the scope of activity, not replaces it. It is inexpedient, in our opinion, to define competence as a goal, function, goal or task [5, p. 261; 6, p. 190], given that these are independent and different in their legal nature concepts.

However, the essence of the concept of "competence" is detailed depending on the scope of its use and the specifics of the subjects who are endowed with such competence. In particular, the developer of the theory of competence Yu. A. Tikhomirov claimed that the latter is a set of public affairs which are entrusted in the 
manner prescribed by law to a particular entity [7, p. 53-54]. Yu. P. Bytyak understands competence as a significant "volume of state activity assigned to a specific body or range of issues provided by law, other regulations, which he has the right to decide in the process of practical activities" [8, p. 64]. Thus, the competence is a defined in the law the ability to carry out certain activities, to exercise their powers (traditionally - a set of rights and responsibilities) within its subject matter. Accordingly, the content of the competence of a body is the authority and the subject of jurisdiction - these are elements of the structure of the concept of "competence".

Yu. O. Tikhomirov proposes to define similar elements that make up the structure of competence: "a) normatively established goals, which mean a way of long-term normative orientation of subjects of law and sustainable activity to achieve these goals. In a broad sense, we mean public functions, without which society and the state can not ensure their livelihood and existence; b) subjects of jurisdiction as legally defined spheres and objects of influence; c) power as a legally guaranteed measure of decision-making and action "[7, p. 55-56], as well as as an additional element of liability for non-performance or improper performance of duties, and is a kind of public law guarantee. We cannot unequivocally agree with the attribution of goals, objectives and responsibilities to the structure of competence, because these elements are components of the administrative and legal status.

In our opinion, in order to investigate the competence of the subjects of free legal aid, it is necessary to: first, determine the general subject matter; secondly, to systematize the rights and responsibilities (powers) of each of these entities, as well as on the basis of such systematization to conduct a general analysis and identify common competence blocks for entities providing free legal aid, which in the future may be defined as areas of activity. Meanwhile, it should be noted that the category of competence is specific to the body or official, not an individual, including a lawyer, so in this section will focus on bodies providing free legal aid, specialized institutions and centers for free legal aid. It is advisable to take into account not only the direct provision of free legal services, but also the organizational aspects of such activities.

The subject of jurisdiction in this case, we determine the scope of free legal aid, the general management of which in accordance with paragraph 8 of the Regulation on the Ministry of Justice approved by the Cabinet of Ministers of Ukraine from 2.07. 2014 № 228 [9] is carried out by the Ministry of Justice of Ukraine, its interregional bodies together with the Coordination Center for Legal Aid.

As we have already noted in the executive authorities, first of all the Ministry of Justice of Ukraine and its interregional bodies create public receptions for free primary legal aid, the head of which is appointed by the executive body to which it was established, they (executive authorities) must also provide material -technical basis of such reception (premises and material and technical equipment). For its part, the competence of the public reception for the provision of free primary legal aid is enshrined in p. 3.9. and 3.10 of the Procedure for the work of the public reception center for free primary legal aid approved by the order of the Ministry of Justice of Ukraine dated 21.09.2011 № 3047/5, after analyzing which we propose to single out 
the following competence blocks. The first, most important competence block is the direct provision of legal services within the framework of primary legal aid, namely: "provision of legal information; providing advice and clarifications on legal issues; preparation of applications, complaints and other legal documents (except for procedural documents); providing assistance in ensuring a person's access to secondary legal aid and mediation "[10], as well as the organization and documentation in accordance with current legislation of personal reception of citizens who have applied for free legal aid. The second block can be defined as informational, because to perform the tasks assigned to the public reception for free primary legal aid, the latter can obtain the necessary information from government agencies, government agencies and organizations, including current regulations. The next block - personnel, which is associated with the organization of the reception, work with staff, in particular his encouragement for conscientious work. The fourth block is associative, it provides for active interaction with public authorities, as well as the possibility of involving "specialists of executive bodies of the Autonomous Republic of Crimea, territorial bodies of central executive bodies, local executive bodies, local governments, state enterprises, institutions, organizations ( with their consent) to consider issues within their competence "[10].

The general powers of local self-government bodies that provide free primary legal aid (executive bodies of village, settlement, city councils) are contained in Art. 38-1 of the Law of Ukraine "On Local Self-Government in Ukraine" we propose to conditionally divide them into such blocks. The first (professional) block, as in the previous case, is related to the provision of free primary legal aid. It includes the possibility to: consider written and oral requests for free primary legal aid, including those received during a personal reception; provide clarification of the provisions of current legislation; to conduct legal consultations; involve lawyers and other legal professionals. The next is the organizational and managerial unit, which includes powers related to the establishment of institutions for free legal aid and organization of their work, staffing, recruitment, coordination of their activities with other executive bodies within the scope of jurisdiction. The logistics unit provides for their full financing of the provision of material and technical resources for their work. Within the limits of defining the competence of local self-government bodies, there is a control unit, as these bodies control the use of financial resources. The information block is related to the provision of direct legal entities that provide free legal aid with all the necessary information related to the latter. It is also necessary to single out the associative unit, as the relevant entities actively contribute to the work of the centers for the provision of free secondary legal aid. In addition, the powers of local governments in the field of free legal aid include "organization of seminars, conferences on free primary legal aid" [12], in our opinion, such powers can be divided into an independent scientific and methodological unit.

The powers of specialized institutions providing free primary legal aid are set out in the Standard Regulations on the institution for providing free primary legal aid approved by the order of the Ministry of Justice of Ukraine dated 28.03.2012 № $483 / 5$ and relate to: providing primary and secondary free legal aid, namely 
consideration of appeals on the provision of free legal aid, the provision of legal information, clarifications and consultations, the preparation of legal documents, other than procedural, as well as ensuring access of persons to the provision of secondary legal aid (professional unit); organization of own activity for the quality of which is responsible; solution of personnel issues (organizational and managerial unit); generalization and analysis of information about the subjects who were provided with free primary legal aid, its quality; dissemination among the population of information on the possibility of receiving free primary legal aid (information and analytical unit); publication of organizational and administrative documents (acts) by the head of the institution (normative block).

Centers for free legal aid operate on the basis of the Regulation on centers for free secondary legal aid approved by the order of the Ministry of Justice of Ukraine dated 02.07.2012 № 967/5 [12], it also enshrines the powers of both regional and local centers that can provide primary and secondary legal aid.

The competence of the regional centers for free secondary legal aid consists of: 1) a professional unit which includes the authority to provide free primary and secondary legal aid, in particular provides protection of the person (participation of the defender during the pre-trial investigation and court proceedings, including an agreement or contract with him, issuing instructions or making a decision to replace him or terminate the provision of free secondary legal aid); 2) the analytical block provides for the collection and generalization of information on the provision of free legal aid and legal services, study of public satisfaction with legal services, statistical information on the number, subjects and results of appeals, as well as systematic reporting on regional and local centers on the provision of free secondary legal aid; 3 ) the monitoring unit includes the authority to supervise the work of local centers of free secondary legal aid and evaluate their activities, as well as direct supervision of lawyers' compliance with the standards of free legal aid and control over the work of local centers; 4) the methodological and educational unit combines the powers to exercise the right to education and the right to educational work, providing advisory and methodological assistance to local centers for free legal aid, dissemination of the practice of providing legal services to the population free of charge; 5) the strategic block envisages the need to plan the activities of free legal aid centers and its observance in the process of carrying out their activities in the field of free legal aid; 6) the personnel block of powers is realized in the part of the organization of advanced training of the personnel of the centers of granting of free legal aid and lawyers; 7) the associative block concerns the powers to coordinate the work of local centers that provide free legal aid and interact with public authorities, local governments, legal entities and individuals, enters into agreements, issues powers of attorney to represent the interests of the regional center; 8) the normative block follows from the powers of the director of the regional center who is authorized to issue administrative acts (organizational and administrative orders).

The competence of local centers for free legal aid differs slightly from regional ones in the absence of such a competent unit as monitoring, instead the analysis of the powers of these entities makes it possible to identify the organizational unit 
related to remote points of free legal aid, and visits to persons in need of legal aid at their place of residence.

The separate competence blocks of the subjects of free legal aid provide an opportunity to form an objective idea of their general competence and the similarity of its individual elements. The difference in this case mainly depends on the level and scope of implementation of such competence by the subjects of free legal aid and the types of the latter - primary or secondary. Thus, the competence of local governments that provide free primary legal aid (executive bodies of village, town, city councils) consists of the following blocks: professional; organizational and managerial; control; informative; associative; scientific and methodical and logistics unit. Specialized institutions that provide free primary legal aid implement the following competence blocks: professional; organizational and managerial; information-analytical and normative.

The competence of the regional centers for free secondary legal aid consists of: a professional unit; analytical unit; monitoring unit; methodical and educational block; strategic block; personnel block; associative block; regulatory unit. The structural blocks of the competence of local centers for the provision of free legal aid in their content are similar to the competence of regional centers with minor differences: professional block; analytical unit; organizational unit; methodical and educational block; strategic block; personnel unit; associative block; regulatory unit.

Discussion. Outlining the rights and responsibilities of specific subjects of free legal aid made it possible to consider their competence within the following separate blocks:

professional - related to the authority to provide primary and secondary free legal aid;

normative - contains the authority to issue acts of an administrative nature in order to organize the internal activities of these entities;

organizational and managerial - involves the implementation of various measures aimed at internal and external organization of the work of a particular entity, the provision of free legal aid, the implementation of other tasks set before him;

control - includes the authority to exercise control over the work of the subjects of free legal aid and the quality of its provision;

monitoring - certain rights and obligations to carry out supervisory activities under the procedures and conditions for providing free legal aid to the population;

personnel - a set of powers for the selection of personnel of the subjects of free legal aid, training, disciplinary liability and the use of incentives;

strategic - related to long-term, short-term and current planning of the activities of free legal aid in both professional and managerial areas;

analytical - the authority to collect, summarize and publish information on quantitative and qualitative indicators of free legal aid to the population;

information - rights and responsibilities regarding informing the population about the possibility, procedure and conditions of receiving free legal aid; 
logistics - provides for the implementation of specific rights aimed at providing the necessary material and technical conditions for the provision of free legal services such as premises, office supplies, office equipment, etc .;

methodological and educational - powers related to the provision of explanations and consultations of a methodological nature to employees of bodies and institutions that provide free legal aid, and directly to persons who plan to receive it;

scientific - establishes the rights and responsibilities of entities that provide free legal aid, aimed at systematically improving the professional level of employees of relevant bodies and institutions, in particular by organizing and conducting scientific events (conferences, round tables, etc.);

associative - consists of a set of powers that enable such entities to interact with each other in the system of free legal aid and outside them, at the national and international levels.

Conclusions. At the same time, the definition of the system of legal aid entities and the delineation of their competence do not reveal the essence of the administrative-legal mechanism of free legal aid, nor does it contribute to the formation of understanding of the procedure and grounds for providing legal services. Therefore, a promising area of further research is the study of other elements of the administrative and legal mechanism of free legal aid, namely: the grounds, procedure and forms of free legal aid in Ukraine and administrative and legal cooperation of free legal aid in Ukraine.

\section{References:}

1. Busel V.T. (2005). Large explanatory dictionary of the modern Ukrainian language. Kyiv; Irpen: Perun. $1728 \mathrm{p}$.

2. Kalashnik V.S. (2009). Explanatory dictionary of the modern Ukrainian language. Common vocabulary. Kharkiv. 960 p.

3. Popular legal encyclopedia (2002). / V.K. Gizhevsky, V.V. Glovchenko, V.S. Kovalsky [etc.]. K .: Jurinkom Inter. $528 \mathrm{p}$.

4. Skakun O.F. (2000). Theory of State and Law: a textbook. 704 p.

5. Averyanov V.B. (2007). Administrative law of Ukraine. Academic course: textbook.. 592 p.

6. Bahrakh D.N., Rossinsky B.V., Starilov Y.N. (2007). Administrative law: a textbook. 816 p.

7. Tikhomirov Yu. A. (2001). Theory of competence. 355 p.

8. Bityak Y.P. (2003). Administrative law of Ukraine. 576 p.

9. On approval of the Regulation on the Ministry of Justice of Ukraine: Resolution of the Cabinet of Ministers of Ukraine of 02.07. 2014 № 228. Official Gazette of Ukraine. 2014. № 54. Art. 1455

10. On approval of the Procedure for the work of the public reception center for the provision of free primary legal aid: order of the Ministry of Justice of Ukraine dated 21.09.2011 № 3047/5. Official Gazette of Ukraine. 2011. № 75. Art. 2819

11. On local self-government in Ukraine: Law of Ukraine 21.05.1997 № 280/97-VR. Information of the Verkhovna Rada of Ukraine. 1997. № 24. Art. 170.

12. On approval of the Regulations on centers for the provision of free secondary legal aid: order of the Ministry of Justice of Ukraine dated 02.07.2012 № 967/5. Official Gazette of Ukraine. 2012. № 50. Art. 2002.

13. Marchenko, V., \& Protsevsky, V. (2020). CONSTITUTIONAL AND LEGAL REGULATION OF THE STATUS OF THE HEAD OF GOVERNMENT IN THE MIXED-TYPE REPUBLICS. Public Administration and Law Review, (2), 28-35. https://doi.org/10.36690/2674-5216-2020-2-28. 